\title{
Marichromatium bheemlicum sp. nov., a non-diazotrophic, photosynthetic gammaproteo- bacterium from a marine aquaculture pond
}

Correspondence
Ch. Sasikala
r449@sify.com or
sasi449@yahoo.ie

The genus Marichromatium was established to separate the true marine species of the genus Chromatium from their freshwater counterparts (Imhoff et al., 1998). At present, the genus Marichromatium comprises three described species, Marichromatium gracile (Imhoff et al., 1998) (originally described as Chromatium gracile; Strzeszewski, 1913),

The GenBank/EMBL/DDBJ accession number for the $16 \mathrm{~S}$ rRNA gene sequence of strain $\mathrm{JA} 124^{\top}$ is $\mathrm{AM} 180952$.

Phase-contrast and electron micrograph images of cells of strain $\mathrm{JA} 124^{\top}$ and absorption spectra of a whole-cell extract and acetoneextracted pigments are available as supplementary material with the online version of this paper.
Marichromatium purpuratum (Imhoff et al., 1998) (originally described as Chromatium purpuratum; Imhoff \& Trüper, 1980) and Marichromatium indicum (Arunasri et al., 2005). In this communication, we propose a novel species of this genus which has properties distinct from all other Marichromatium species based on phenotypic and phylogenetic analysis.

Strain JA12 $4^{\mathrm{T}}$ was isolated from enrichments of a sediment and water sample from an aquaculture pond near Bheemli, Visakhapatnam (India). The medium of Pfennig (Pfennig \& Trüper, 1992) supplemented with $\mathrm{NaCl}(3 \%, w / v)$, pyruvate $(0.3 \%, w / v)$ as a carbon source/electron donor and 
ammonium chloride $(0.12 \%)$ as a nitrogen source was used for photoheterotrophic growth under fluorescent light $(2400 \mathrm{~lx})$ at $30 \pm 2{ }^{\circ} \mathrm{C}$. Purification was achieved by repeated agar-shake dilution series (Pfennig \& Trüper, 1992; Imhoff, 1988; Trüper, 1970). Purified cultures were grown in completely filled screw-capped test tubes $(10 \times 100 \mathrm{~mm})$ for photoheterotrophic growth. Morphological properties (cell shape, cell division, cell size, flagella) were observed by light microscopy (with an Olympus BH-2 microscope). To study the ultrastructure of the flagella, cells were stained with $1 \%$ phosphotungstic acid; ultrathin sections were viewed through a transmission electron microscope (H-7500; Hitachi) to examine intracytoplasmic structures such as the internal membrane system. In vivo absorption spectra were measured with a Spectronic Genesys 2 spectrophotometer using sucrose solution for cell suspension (Pfennig \& Trüper, 1992). Absorption spectra were also recorded of pigments extracted with acetone from the cell suspension. Cellular components (fatty acids, intracellular and membrane proteins, polysaccharides, photosynthetic pigments and nucleic acids) of strain JA124 $4^{\mathrm{T}}$ were compared with cells from Mch. indicum DSM $15907^{\mathrm{T}}$ based on information obtained from Fourier-transform infrared (FTIR) spectroscopy as described previously (Ramana et al., 2006).

The total cellular protein profile of strain JA124 ${ }^{\mathrm{T}}$ was compared with that of Mch. indicum DSM $15907^{\mathrm{T}}$ as follows. The strains were grown under similar conditions, cells were lysed and protein profiles were obtained by SDS-PAGE (Sorokin et al., 2004). After electrophoresis, the gels were silver stained to visualize the protein bands. The utilization of different carbon substrates and electron donors $(0.3 \%$, w $/ \mathrm{v}$ or $\mathrm{v} / \mathrm{v}$, unless otherwise mentioned) was tested in the medium of Pfennig (Pfennig \& Trüper, 1992) containing $5 \mathrm{mM} \mathrm{Na}_{2} \mathrm{~S} \cdot 9 \mathrm{H}_{2} \mathrm{O}$. Ammonium chloride was replaced with different nitrogen sources in order to test for utilization of nitrogen sources $(0.12 \%, \mathrm{w} / \mathrm{v})$. Diazotrophy of the culture was determined by growing strain JA124 $4^{\mathrm{T}}$ under a $\mathrm{N}_{2}$ atmosphere and was confirmed by repeated subculturing (four times). Cultures of strain JA124 ${ }^{\mathrm{T}}$ in the exponential phase grown photoheterotrophically (pyruvate, sulfide and ammonium chloride as carbon, electron and nitrogen sources, respectively) were used to assay for acetylene reduction activity as described earlier (Sasikala et al., 1990). Growth was measured turbidometrically at $660 \mathrm{~nm}$. Genomic DNA was extracted and purified according to the method of Marmur (1961) and the G $+C$ content of the DNA was determined by HPLC (Mesbah et al., 1989). 16S rRNA gene sequence analysis was carried out as described by Srinivas et al. (2006). Briefly, sequences were aligned using the CLUSTAL W program (Thompson et al., 1994) and the alignment was corrected manually. The CLUSTAL $\mathrm{W}$ alignment file was used as input file to the SEQBOOT program in the PHYLIP package (Felsenstein, 1989) and the output file of SEQBOOT was used as the input file for maximum-likelihood analysis with 100 datasets and five times jumbling. One single tree was generated using 100 trees generated during maximum-likelihood analysis using the CONSENSE program.
The distance matrix was calculated on the basis of the algorithm of Jukes \& Cantor (1969) with the DNADIST program within the PHYLIP package. The FITCH program in the PHYLIP package was employed to fit a tree to the evolutionary distances using the DIST file as infile and the CONSENSE file as intree. DNA-DNA hybridization was conducted by the Identification Service of the DSMZ (Braunschweig, Germany), using a spectrophotometric method (De Ley et al., 1970; Huß et al., 1983) after chromatographic (hydroxyapatite) purification of DNA (Cashion et al., 1977).

Sediment and water samples were collected on 24 February 2005 at around midday from an aquaculture pond near the sea (Bay of Bengal) at Bheemli, India. GPS positioning of the sample collection site is $17^{\circ} 51^{\prime} 41.03^{\prime \prime} \mathrm{N} 83^{\circ} 25^{\prime}$ $16.81^{\prime \prime}$ E. The sample yielding strain JA124 ${ }^{\mathrm{T}}$ had a $\mathrm{pH}$ of 6.8 , a salinity of $2-3 \% \mathrm{NaCl}$ and a temperature of $30^{\circ} \mathrm{C}$. Individual cells of strain JA124 ${ }^{\mathrm{T}}$ were rod-shaped (Supplementary Fig. S1, available in IJSEM Online), $0.8-1.0 \mu \mathrm{m}$ wide and $2-4 \mu \mathrm{m}$ long. The cells were highly motile with single polar flagella and multiplied by binary fission. Electron photomicrographs of ultrathin sections of the cells revealed a vesicular type of internal membranes (Supplementary Fig. S2).

Strain JA124 ${ }^{\mathrm{T}}$ grows well photo-organoheterotrophically (optimum light intensity is $2400 \mathrm{~lx}$ ). Strain JA124 ${ }^{\mathrm{T}}$ was able to grow photolithoautotrophically [anaerobically in the light (2400 lx) with $\mathrm{Na}_{2} \mathrm{~S} .9 \mathrm{H}_{2} \mathrm{O}$ or $\mathrm{Na}_{2} \mathrm{~S}_{2} \mathrm{O}_{3}(1.0 \mathrm{mM}$ ) as electron donors with $\mathrm{NaHCO}_{3}(0.1 \%, \mathrm{w} / \mathrm{v})$ as carbon source] and photolithoheterotrophically [anaerobically in the light (2400 lx) with $\mathrm{Na}_{2} \mathrm{~S} .9 \mathrm{H}_{2} \mathrm{O}$ or $\mathrm{Na}_{2} \mathrm{~S}_{2} \mathrm{O}_{3}(1.0 \mathrm{mM})$ as electron donors and organic substrates $(0.3 \%, \mathrm{w} / \mathrm{v})$ as carbon source]. Chemolithoautotrophy [aerobically in the dark with thiosulfate $(1.0 \mathrm{mM})$ as electron donor and $\mathrm{NaHCO}_{3}$ $(0.1 \%, \mathrm{w} / \mathrm{v})$ as carbon source], chemo-organoheterotrophy and a fermentative mode of growth [anaerobically in the dark, pyruvate as fermentable substrate $(0.3 \%$, w/v)] could not be demonstrated. Substrates that were utilized as carbon sources/electron donors under photolithoheterotrophic conditions included acetate, pyruvate, succinate, fumarate, glycerol, ethanol, methanol, malate, valerate and caproate (Table 1). Those that could not be utilized included citrate, glucose, mannitol, lactate, tartrate, benzoate and glutamate. Thiosulfate, sulfate, sulfite, thioglycollate, cysteine and sodium sulfide were utilized as sulfur sources under phototrophic conditions. Ammonium chloride, glutamate and glutamine were utilized as nitrogen sources, while nitrate, nitrite, urea and molecular nitrogen did not support growth. Acetylene reduction activity for the enzyme nitrogenase was also not observed in strain JA124 ${ }^{\mathrm{T}}$. Salt is obligatory for growth of strain JA124 ${ }^{\mathrm{T}}$, and growth occurs in $1.5-11 \%$ $\mathrm{NaCl}(\mathrm{w} / \mathrm{v})$, with optimum growth at $1.5-8.5 \%(\mathrm{w} / \mathrm{v})$. The $\mathrm{pH}$ range for growth of strain JA124 $4^{\mathrm{T}}$ is $\mathrm{pH}$ 6.0-8.5, with optimum growth at $\mathrm{pH} 6.5-8.5$. The temperature range for growth is $20-35^{\circ} \mathrm{C}$, and the optimum is at $30-35^{\circ} \mathrm{C}$. Yeast extract is required as a growth factor $(0.03 \%, w / v)$. In the 
Table 1. Differentiating characteristics of species of the genus Marichromatium

Organic substrate utilization was tested during photolithoheterotrophic growth in the presence of $\mathrm{Na}_{2} \mathrm{~S} .9 \mathrm{H}_{2} \mathrm{O}$ ( $5 \mathrm{mM}$ ). Substrates that were utilized by all of the strains include acetate, pyruvate and malate; those that could not be utilized include glutamate, glucose, mannitol and benzoate. Other similarities include rod-shaped cells, cell division by binary fission, the presence of a single polar flagellum and vesicular internal membrane. +, Substrate utilized; -, substrate not utilized; NR, not reported. Data for reference taxa were taken from Pfennig \& Trüper (1989), Caumette et al. (1997) and Arunasri et al. (2005).

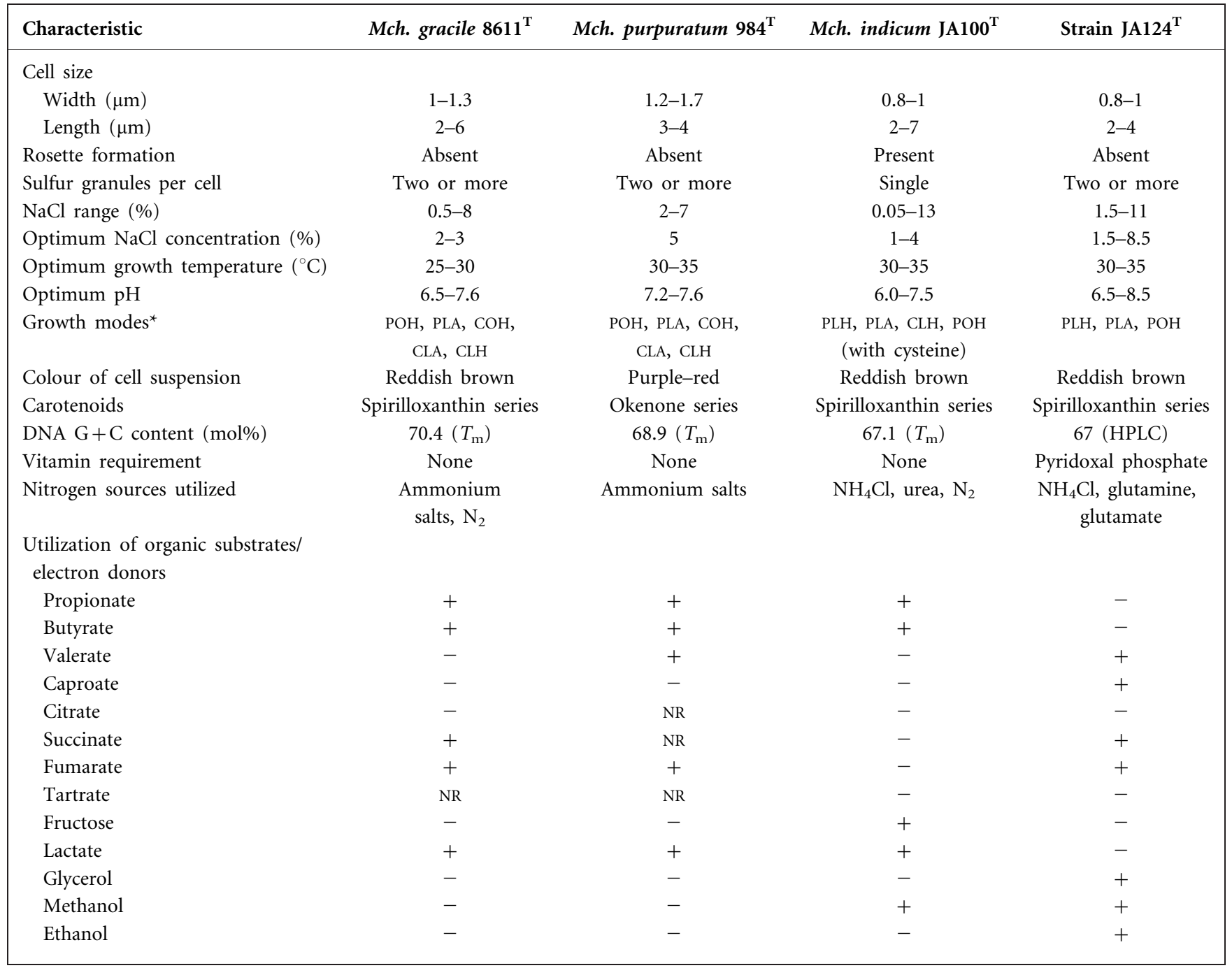

${ }^{*} \mathrm{CLA}$, Chemolithoautotrophy; CLH, chemolithoheterotrophy; $\mathrm{COH}$, chemo-organoheterotrophy; PLA, photolithoautotrophy; PLH, photolithoheterotrophy; $\mathrm{POH}$, photo-organoheterotrophy.

absence of yeast extract, pyridoxal phosphate $\left(100 \mu \mathrm{g}^{-1}\right)$ is required for growth of strain JA124 ${ }^{\mathrm{T}}$.

The colour of photosynthetically grown cultures of strain $\mathrm{JA} 124^{\mathrm{T}}$ is reddish brown. The whole-cell absorption spectrum (Supplementary Fig. S3a) of strain JA124 ${ }^{\mathrm{T}}$ showed absorption maxima at 374, 488, 590, 797 and $851 \mathrm{~nm}$, confirming the presence of bacteriochlorophyll $a$, and the absorption spectrum of pigments extracted with acetone (Supplementary Fig. S3b) gave absorption maxima at 475 and $502 \mathrm{~nm}$, indicating the presence of the spirilloxanthin series of carotenoids. FTIR spectroscopic analysis of strain
$\mathrm{JA} 124^{\mathrm{T}}$ in comparison with $\mathrm{Mch}$. indicum JA100 ${ }^{\mathrm{T}}$ showed no notable spectral differences between the strains (data not shown), indicating little or no difference in the chemical composition of these bacteria. However, significant differences were observed between the two bacteria in protein patterns (Fig. 1).

The DNA base composition of strain JA124 ${ }^{\mathrm{T}}$ was $67 \mathrm{~mol} \%$ $\mathrm{G}+\mathrm{C}$ (by HPLC). The phylogenetic relationship of strain $\mathrm{JA} 124^{\mathrm{T}}$ to other purple sulfur bacteria was examined by $16 \mathrm{~S}$ rRNA gene sequencing. The data obtained revealed that the sequence of the new isolate was included in the cluster of the 


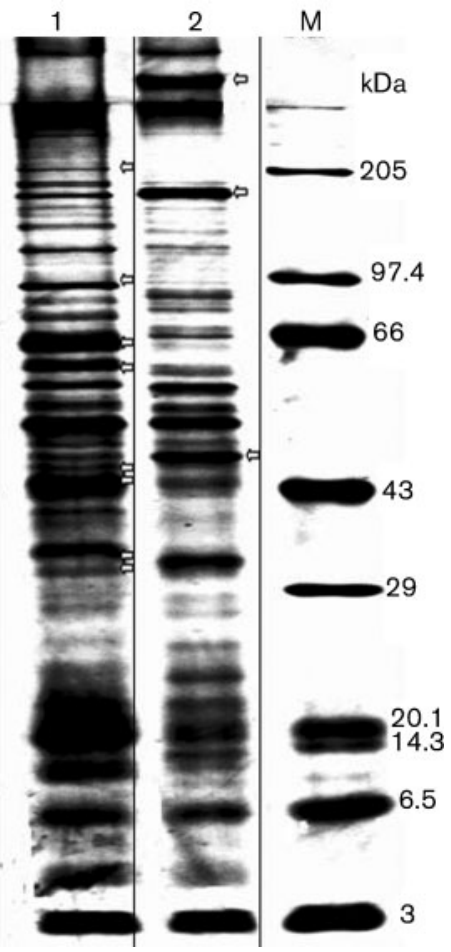

Fig. 1. Protein banding patterns of cell lysates, visualized with silver staining after SDS-PAGE, of Mch. indicum DSM $15907^{\top}$ (lane 1) and strain $\mathrm{JA} 124^{\top}$ (lane 2). Lane M, molecular mass standards $(\mathrm{kDa})$. Arrows indicate differences.

genus Marichromatium (Fig. 2) but was distinct from other species of the genus. The highest sequence similarities of strain JA124 $4^{\mathrm{T}}$ were found with the type strains of $\mathrm{Mch}$. indicum (98\%), Mch. purpuratum (95\%) and Mch. gracile
(93\%). However, DNA-DNA hybridization with $M c h$. indicum DSM $15907^{\mathrm{T}}$ revealed a relatedness of only $65 \%$ with strain JA124 ${ }^{\mathrm{T}}$. Apart from the $16 \mathrm{~S}$ rRNA gene sequence dissimilarity and DNA-DNA hybridization studies, strain $\mathrm{JA} 124^{\mathrm{T}}$ showed clear phenotypic differences from other Marichromatium species (Table 1) that justify the description of a novel species, Marichromatium bheemlicum sp. nov.

\section{Description of Marichromatium bheemlicum sp. nov.}

Marichromatium bheemlicum (bheem'li.cum. N.L. neut. adj. bheemlicum named after Bheemli, the place from which the type strain was isolated).

Cells are rod-shaped, $0.8-1.0 \mu \mathrm{m}$ wide and $2-4 \mu \mathrm{m}$ long, motile and multiply by binary fission. Gram-negative. Growth occurs under anaerobic conditions in the light (photolithoautotrophy, photolithoheterotrophy and photoorganoheterotrophy). Internal photosynthetic membranes are of the vesicular type. The colour of phototrophic cultures is reddish brown. The in vivo absorption spectrum of intact cells in sucrose exhibits maxima at 374, 488, 590, 797 and $851 \mathrm{~nm}$. Photosynthetic pigments are bacteriochlorophyll $a$ and probably carotenoids of the spirilloxanthin series. The type strain is mesophilic (temperature range $20-35^{\circ} \mathrm{C}$ ), with a $\mathrm{pH}$ optimum at $6.5-8.5$, and requires $\mathrm{NaCl}$ (range 1.5-11\%) for growth. Photolithoheterotrophy with various organic compounds is the preferred mode of growth. Good carbon sources are acetate, pyruvate and intermediates of the citric acid cycle except citrate. Growth also occurs on glycerol and caproate. Thiosulfate, sulfate, sulfite, thioglycollate, cysteine and sodium sulfide are utilized as sulfur sources under phototrophic conditions. Photolithoautotrophic growth occurs. Diazotrophic growth and acetylene reduction activity are absent.

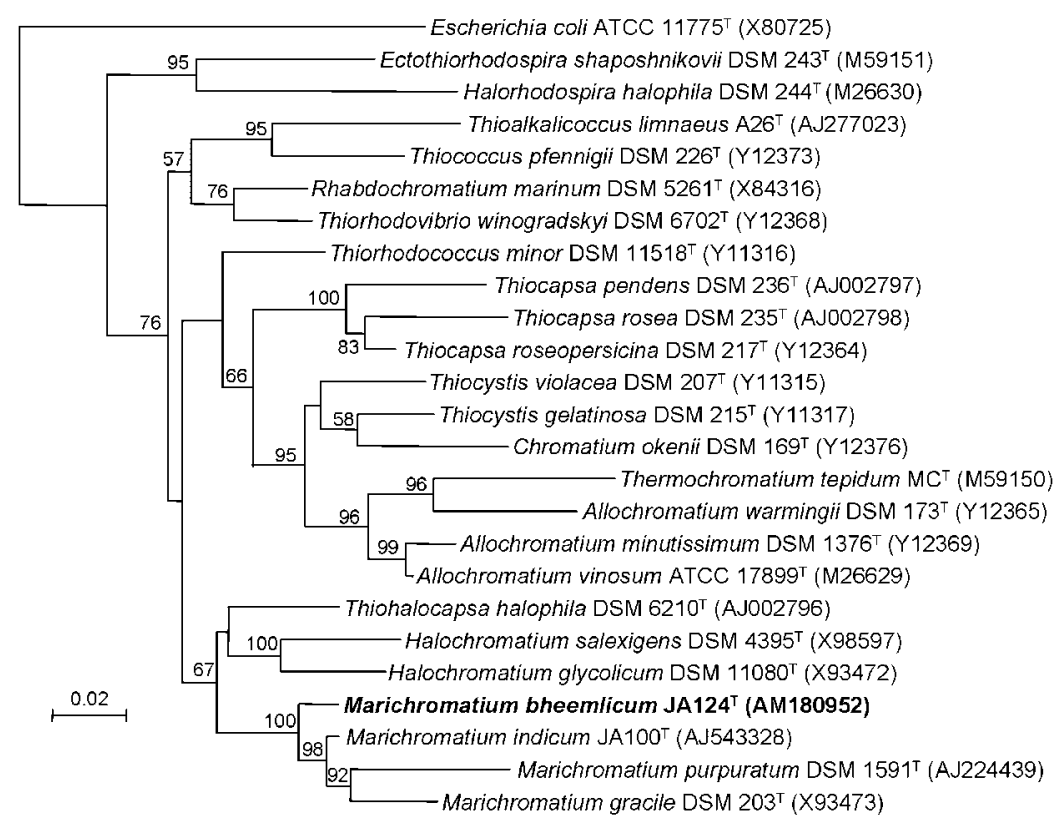

Fig. 2. Dendrogram depicting the phylogenetic relationships of strain $\mathrm{JA} 124^{\top}$ within the family Chromatiaceae determined using $16 \mathrm{~S}$ rRNA gene sequence analysis. See text for details. Bar, 2 nucleotide substitutions per 100 nucleotides. 
Pyridoxal phosphate is required for growth of the type strain. The DNA base composition is $67 \mathrm{~mol} \% \mathrm{G}+\mathrm{C}$ (by HPLC).

The type strain, JA124 ${ }^{\mathrm{T}} \quad\left(=\mathrm{ATCC}\right.$ BAA- $1316^{\mathrm{T}}=\mathrm{JCM}$ $\left.13911^{\mathrm{T}}\right)$, was isolated from a marine aquaculture pond exposed to light at Bheemli, on the Bay of Bengal in India.

\section{Acknowledgements}

Financial assistance received from Department of Biotechnology, Government of India, is acknowledged. P.A.K. and T.N.R.S. acknowledge the CSIR, Government of India, for the award of JR/SR fellowships. The skilful assistance of F. Lappe (IFM-GEOMAR, Kiel) in molecular analysis and Mercy Rose Stella (JNTU) for SDS-PAGE analysis is gratefully acknowledged. Financial assistance received under the DST-DAAD exchange program (grant 422-PPP-34105) is acknowledged.

\section{References}

Arunasri, K., Sasikala, C., Ramana, C. V., Süling, J. \& Imhoff, J. F. (2005). Marichromatium indicum sp. nov., a novel purple sulfur gammaproteobacterium from mangrove soil of Goa, India. Int J Syst Evol Microbiol 55, 673-679.

Cashion, P., Holder-Franklin, M. A., McCully, J. \& Franklin, M. (1977). A rapid method for the base ratio determination of bacterial DNA. Anal Biochem 81, 461-466.

Caumette, P., Imhoff, J. F., Süling, J. \& Matheron, R. (1997). Chromatium glycolicum sp. nov., a moderately halophilic purple sulfur bacterium that uses glycolate as substrate. Arch Microbiol 167, 11-18.

De Ley, J., Cattoir, H. \& Reynaerts, A. (1970). The quantitative measurement of DNA hybridization from renaturation rates. Eur J Biochem 12, 133-142.

Felsenstein, J. (1989). PHYLIP (phylogeny inference package), version 3.5.1. Distributed by the author. Department of Genome Sciences, University of Washington, Seattle, USA.

Huß, V. A. R., Festl, H. \& Schleifer, K. H. (1983). Studies on the spectrophotometric determination of DNA hybridization from renaturation rates. Syst Appl Microbiol 4, 184-192.

Imhoff, J. F. (1988). Anoxygenic phototrophic bacteria. In Methods in Aquatic Bacteriology, pp. 207-240. Edited by B. Austin. Chichester: Wiley.

Imhoff, J. F. \& Trüper, H. G. (1980). Chromatium purpuratum, sp. nov., a new species of the Chromatiaceae. Zentralbl Bakteriol Parasitenkd Infektionskr Hyg Abt 1 Orig [C] 1, 61-69.

Imhoff, J. F., Süling, J. \& Petri, R. (1998). Phylogenetic relationships among the Chromatiaceae, their taxonomic reclassification and description of the new genera Allochromatium, Halochromatium, Isochromatium, Marichromatium, Thiococcus, Thiohalocapsa and Thermochromatium. Int J Syst Bacteriol 48, 1129-1143.

Jukes, T. H. \& Cantor, C. R. (1969). Evolution of protein molecules. In Mammalian Protein Metabolism, pp. 21-132. Edited by H. N. Munro. New York: Academic Press.

Marmur, J. (1961). A procedure for the isolation of deoxyribonucleic acid from microorganisms. J Mol Biol 3, 208-218.

Mesbah, M., Premachandran, U. \& Whitman, W. B. (1989). Precise measurement of the $\mathrm{G}+\mathrm{C}$ content of deoxyribonucleic acid by high-performance liquid chromatography. Int J Syst Bacteriol 39, 159-167.

Pfennig, N. \& Trüper, H. G. (1989). Purple bacteria. In Bergey's Manual of Systematic Bacteriology, vol. 3, pp. 1637-1653. Edited by J. T. Staley, M. P. Bryant, N. Pfennig \& J. G. Holt. Baltimore: Williams \& Wilkins.

Pfennig, N. \& Trüper, H. G. (1992). The family Chromatiaceae. In The Prokaryotes. A Handbook on the Biology of Bacteria. Ecophysiology, Isolation, Identification, Applications, 2nd edn, pp. 3200-3221. Edited by A. Balows, H. G. Trüper, M. Dworkin, W. Harder \& K. H. Schleifer. Berlin, Heidelberg, New York: Springer.

Ramana, Ch. V., Sasikala, Ch., Arunasri, K., Anil Kumar, P., Srinivas, T. N. R., Shivaji, S., Gupta, P., Suling, J. \& Imhoff, J. F. (2006). Rubrivivax benzoatilyticus sp. nov., an aromatic hydrocarbondegrading purple betaproteobacterium. Int J Syst Evol Microbiol 56, 2157-2164.

Sasikala, K., Ramana, Ch. V., Raghuveer Rao, P. \& Subrahmanyam, M. (1990). Photoproduction of hydrogen, nitrogenase and hydrogenase activities of free and immobilized whole cells of Rhodobacter sphaeroides OU 001. FEMS Microbiol Lett 72, 23-28.

Sorokin, D. Y., Tourova, T. P., Antipov, A. N., Muyzer, G. \& Kuenen, J. G. (2004). Anaerobic growth of the haloalkaliphilic denitrifying sulfur-oxidizing bacterium Thialkalivibrio thiocyanodenitrificans sp. nov. with thiocyanate. Microbiology 150, 2435-2442.

Srinivas, T. N. R., Anil Kumar, P., Sasikala, Ch., Ramana, Ch. V., Süling, J. \& Imhoff, J. F. (2006). Rhodovulum marinum sp. nov., a novel phototrophic purple non-sulfur alphaproteobacterium from marine tides of Visakhapatnam, India. Int J Syst Evol Microbiol 56, 1651-1656.

Strzeszewski, B. (1913). Beiträge zur Kenntnis der Schwefelflora in der Umgebung von Krakau. Bull Acad Sci Cracovie [B], 309-334 (in German).

Thompson, J. D., Higgins, D. G. \& Gibson, T. J. (1994). CLUSTAL W: improving the sensitivity of progressive multiple sequence alignment through sequence weighting, position-specific gap penalties and weight matrix choice. Nucleic Acids Res 22, 4673-4680.

Trüper, H. G. (1970). Culture and isolation phototrophic sulfur bacteria from the marine environment. Helgol Wiss Meeresunters 20, 6-16. 